OmniAkuatika, 12 (1): 22-29, 2016
ISSN: 1858-3873 print / 2476-9347 online
Research Article

\title{
Identifikasi Penjalaran Gelombang Panjang Samudera Hindia Ke Selat Lombok Berdasarkan Komponen Harmonik Arus
}

\author{
Yogo Pratomo ${ }^{1 *}$, Widodo Setiyo Pranowo ${ }^{1,2}$, Hendrawan Setiadi ${ }^{1,4}$, \\ Gentio Harsono $^{1,3}$, Kamija ${ }^{1,3}$, Sahat Monang Simanjuntak ${ }^{1,3}$, Tasdik Mustika Alam ${ }^{1}$ \\ ${ }^{1}$ Sekolah Tinggi Teknologi Angkatan Laut, Jurusan Teknik Hidrografi,Jl. Pantai Kuta V N. 1, Ancol Timur, \\ Jakarta Utara. \\ ${ }^{2}$ Laboratorium Data Laut dan Pesisir, Badan Penelitian dan Pengembangan Kementerian Kelautan dan \\ Perikanan, Ancol Timur, Jakarta.Telp/Fax. (024) 7476498, 0812326091280. \\ ${ }^{3}$ Dinas Hidro-Oseanografi, TNI Angkatan Laut,JI. Pantai Kuta V No. 1, Ancol Timur, Jakarta Utara. \\ ${ }^{4}$ Badan Penelitian dan Pengembangan TNI Angkatan Laut,Jl. Pondok Labu, Jakarta, 12440.
}

"Corresponding author : pratomo.boy@gmail.com

\begin{abstract}
The Lombok Strait is one area passing by seawater mass from Pacific Ocean to Indian Ocean, well known as Indonesia Through Flow (ARLINDO). It was profen by the existane of long periode harmonic current component affected by the sun (SA, SSA ), and an influence by moon (MSF). The harmonic current speed has an average of $0.370668 \mathrm{~m} / \mathrm{s}$ in the depths of 100 meters during January 9, 2004 until 14 June 2005 (1.5 years). Time series data ocean current of INSTANT project (2004-2005) is used in this research, analized by using toolbox module of t-tide 1.3 beta. The current rose at 350 meters deep and 450 meters deep shous pattern of the a unique ocean current, which mastly toward to north and northeast (55\%) with velocity at $0.2-1.0 \mathrm{~m} / \mathrm{s}$. The current is coming from Indian Ocean which proven by the existence of components like M4, MS4, MSF, 01. There is also ocean current toward to south and southwest as (45\%) with speed of 0.11-0.9 $\mathrm{m} / \mathrm{s}$. Thie ocean current which coming from Indian Ocean is indication of propagation of long wave penetration to Lombok Strait. During its propagation passing the sill, the wave become an internal wave in Lombok Strait.
\end{abstract}

Keywords: internal wave, indian ocean, lombok strait, harmonic currents component, INSTANT 2004-2005.

\section{Pendahuluan}

Selat Lombok merupakan selat diantara dua pulau yaitu pulau Bali dan pulau Lombok, selat Lombok sendiri memiliki arus yang sangat unik untuk diadakan penelitian, karena selat Lombok terkenal sebagai salah satu lintasan utama Arus Lintas Indonesia (ARLINDO) atau Indonesian Trough Flow. Ekspedisi INSTANT merupakan salah satu program Internasional Nusantara stratification and transport, yang merupakan bagian dari upaya untuk mempelajari dan mendalami lautan Indonesia terhadap pola dan perubahan arus laut karena perairan Indonesia merupakan zona kritikal 'choke point untuk pengukuran arus laut (Pranowo et al, 2005). Ekspedisi INSTANT (The
International NusantaraStratification and Transport), bertujuan untuk mengetahui aliran masa air dari Samudera Pasifik menuju Samudera Hindia yang melalui perairan Indonesia dan berguna untuk memprakirakan variabilitas iklim. Pengukuran dilaksanakan pada beberapa bagian perairan Indonesia yaitu: jalur arus masuk di Selat Makassar dan Lintasan Lifamatola (Lifamatola passage), jalur arus keluar di Pintasan Timor (Timor passage), Selat Lombok, Selat Ombai, dengan periode selama 3 tahun. Ekspedisi INSTANT merupakan kejasama 5 negara yaitu, Indonesia, Amerika Serikat, Australia, Belanda, dan Perancis (Sprintall et al. dalam Gordon et al., 2008).

ARLINDO merupakan suatu sistem 
sirkulasi laut di perairan Indonesia dimana terjadi lintasan arus yang membawa massa air dari Lautan Pasifik ke Lautan Hindia. Massa air Pasifik tersebut terdiri atas massa air Pasifik utara dan Pasifik selatan (Wyrtki, 1961). Gelombang merupakan mekanisme naik turunnya permukaan air secara tegak lurus yang terjadi dalam waktu sesaat sehingga mencapai keseimbangan. Gelombang hampir terjadi disetiap permukaan laut dan kolom air dimanapun baik dalam bentuk gelombang panjang (dalam bentuk arus). Gelombang ini dapat dibangkitkan oleh faktor luar dan internal. Faktor luar seperti angin, grafitasi bulan dan matahari, sedangkan dari fakor internal berasal dari gempa bumi (tsunami) dan perbedaan densitas. Beberapa peneliti menyatakan bahwa gelombang adalah akibat (gangguan) terhadap kolom air dan sebagian lagi menyatakan bahwa gelombang dapat terjadi secara teratur jika diakibatkan oleh gejala pasang surut (Purba dan Pranowo, 2015).

Gelombang pasang surut yang terjadi di suatu perairan yang diamati adalah merupakan penjumlahan dari komponenkomponen pasang surut yang disebabkan oleh grafitasi bulan, matahari, dan bendabenda angkasa lainnya yang mempunyai periode tersendiri. Tipe pasang berbeda-beda dan sangat tergantung dari tempat dimana pasang itu terjadi (Cappenberg, 1992). Pasang surut akan membawa massa air karena pasang surut merupakan gelombang panjang. Walaupun gelombang yang kita ketahui tidak membawa massa air tetapi merambatkan energi, pada kasus pasang surut gelombang yang tejadi merupakan perpindahan massa dalam jarak yang jauh. (Purba dan Pranowo, 2015).
Arus pasut biasanya mempunyai sifat yang saling bertolak belakang (bidirection). Dalam hal ini dapat dilihat pada 2 pasut yang diamati. Pada saat air tinggi, arus akan bergerak dari nalai yang tertinggi ke rendah. Namun pada saat tunggang rendah antara dua pasut, maka arus akan bergerak sebaliknya. Beberapa wilayah perairan yang mempunyai tipe pasang surut seperti di wilayah selat dimana arah pasang dan surut akan melewati selat terus menerus dalam arah yang berlawanan. (Purba dan Pranowo, 2015).

Maka dengan mengetahui perbedaan arah dan kecepatan arus diharapkan kapal selam Indonesia dapat mengetahui waktu yang tepat untuk melaksanakan pelayaran agar terhindar dari bahaya navigasi pelayaran.

\section{Metodologi}

Data ekspedisi INSTANT west mooring deployment 1 merupakan bentuk kerjasama antara 5 negara, yang berada di Selat Lombok dengan koordinat $8^{\circ} 26^{\prime} 20.4^{\prime \prime}$ LS - $115^{\circ} 45^{\prime} 33.12^{\prime \prime}$ BT, data arus tersebut diperoleh dari Laboratorium Data Laut dan Pesisir, Pusat Penelitian dan Pengembangan Sumberdaya Laut dan Pesisir, Badan Penelitian dan Pengembangan Kelautan Perikanan, Kementerian Kelautan dan Perikanan pada mooring Ekspedisi INSTANT yang dilaksanakan pada 9 Januari 2004 s/d 14 Juni 2005. Data yang di Pengolahan data untuk memperoleh komponen harmonik mengunakan Toolbox T-Tide 1.3 beta berbasiskan MatLab (Pawlowicz et al., 2002), yang diilustrasikan pada gambar 1 .

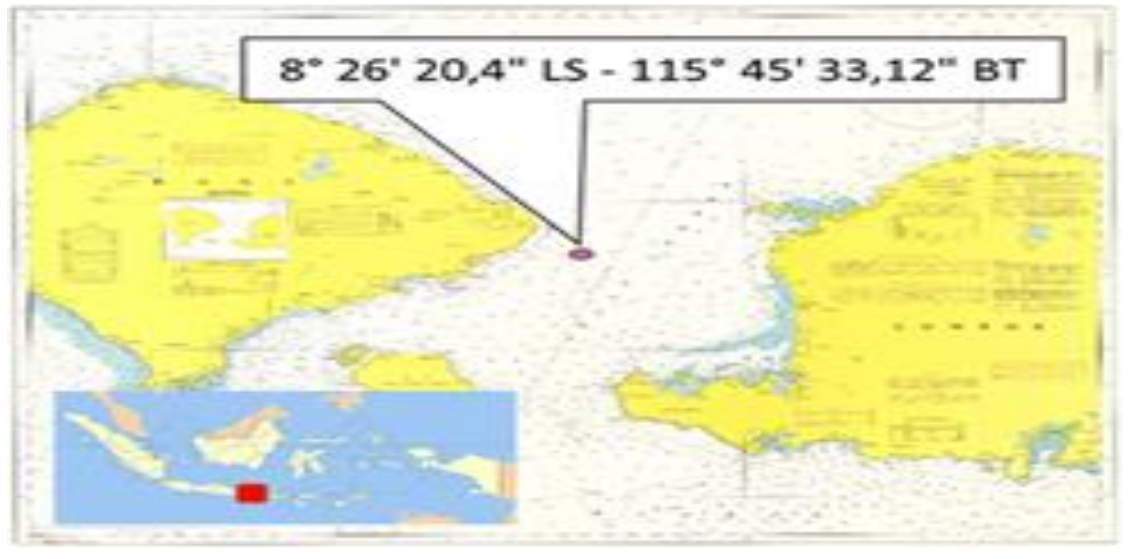

Gambar 1. Letak posisi west mooring deployment 1 (digambar ulang menggunakan peta laut DISHIDROS, 2015). 
24 Omni-Akuatika Vol. 12 No. 1 Mei $2016: 22$ - 29

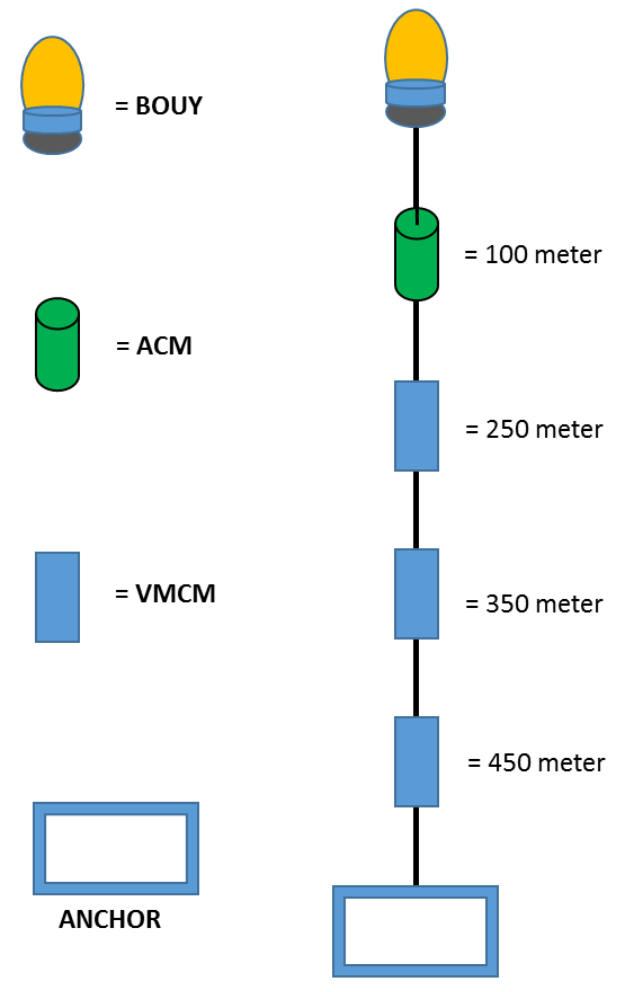

Gambar 2. Pemasangan peralatan pengukuran arus pada INSTANT west mooring deployment $1 \mathrm{di}$ Selat Lombok (digambar ulang berdasarkan letak peralatan Current Meter per kedalaman, 2015).

Data Ekspedisi INSTANT west mooring deployment 1 merupakan data time series. Data tersebut dipergunakan sebagai data utama pada penelitian ini, perekaman data yang diolah adalah data ACM ( Acoustic Current Meter) kedalaman 100 meter, VMCM (Valeport Measuring Current Meter) pada kedalaman 250 meter, 350 meter dan 450 meter. Untuk lebih jelasnya dilihat pada ilustrasi pada Gambar 2.

\section{Hasil dan Pembahasan}

\subsection{Komponen harmonik tiap kedalaman}

Pengaruh pergerakan muka air laut pergerakan arus pada perairan tersebut. Arus harmonik pada perairan selat Lombok memiliki karakteristik yang hampir sama dengan karakteristik pasang surut sehingga memiliki komponen harmonik yang diperoleh dari analisis frekuensi terhadap amplitude dengan konstituen signifikan. Pada

komponen harmonik kedalaman 100 meter s/d 450 meter pada data perekaman mendapatkan komponen harmonik yang signifikan berdasarkan SNR (Significant Noise to Ratio) dibagai menjadi 4 tipe yaitu tipe diurnal, semi diurnal, periode panjang dan tipe perairan dangkal. Pada hasil dari proses kedalaman 100 meter pendapatkan komponen harmonik yang di jelaskan dalam bentuk tabel 2 . 
Tabel 2. Komponen Harmonik Signifikan pada Kedalaman 100 Meter.

\begin{tabular}{|c|c|c|c|c|c|c|c|}
\hline \multicolumn{8}{|c|}{ DIURNAL } \\
\hline tide & freq & amp & amp_err & pha & pha_err & snr & Nama KOMPONEN \\
\hline${ }^{*} \mathrm{~K} 1$ & 0.041781 & 0.0217 & 0.005 & 232.06 & 11.63 & 20 & Luna Solar diurnal \\
\hline${ }^{*} \mathrm{P} 1$ & 0.041553 & 0.0162 & 0.005 & 166.54 & 17.28 & 11 & Principal Solar declination \\
\hline *S1 & 0.041667 & 0.0098 & 0.005 & 15.98 & 41.57 & 4.1 & Solar diurnal \\
\hline${ }^{*} \mathrm{O} 1$ & 0.038731 & 0.0094 & 0.005 & 100.09 & 25.3 & 3.7 & Large Lunar Elliptic Diurnal \\
\hline \multicolumn{8}{|c|}{ SEMI DIURNAL } \\
\hline tide & freq & amp & amp_err & pha & pha_err & snr & Nama KOMPONEN \\
\hline *M2 & 0.080511 & 0.0734 & 0.007 & 270.06 & 5.39 & 120 & Principal lunar semidiurnal \\
\hline *S2 & 0.083333 & 0.0302 & 0.007 & 350.18 & 12.66 & 20 & $\begin{array}{l}\text { Principal Solar Semi Diurnal } \\
\text { Large Lunar eliptik Semi }\end{array}$ \\
\hline *N2 & 0.078999 & 0.0166 & 0.007 & 243.34 & 23.79 & 6.1 & Diurnal \\
\hline *K2 & 0.083562 & 0.0149 & 0.007 & 341.89 & 20.31 & 5 & Lunisolar semidiurnal \\
\hline${ }^{*} \mathrm{MU} 2$ & 0.07769 & 0.0081 & 0.007 & 55.2 & 48.33 & 1.5 & Variational \\
\hline${ }^{*} \mathrm{~T} 2$ & 0.083219 & 0.0076 & 0.007 & 357.85 & 50.21 & 1.3 & Larger solar elliptic \\
\hline \multicolumn{8}{|c|}{ PERIODE PANJANG } \\
\hline tide & freq & amp & amp_err & pha & pha_err & snr & Nama KOMPONEN \\
\hline${ }^{*} \mathrm{MSF}$ & 0.002822 & 0.0343 & 0.016 & 259.99 & 25.9 & 4.9 & Lunisolar synodic fortnightly \\
\hline${ }^{*} \mathrm{SA}$ & 0.000114 & 0.029 & 0.016 & 35.73 & 30.59 & 3.5 & Solar annual \\
\hline *SSA & 0.000228 & 0.0258 & 0.016 & 309.16 & 34.43 & 2.8 & Solar semiannual \\
\hline \multicolumn{8}{|c|}{ PERAIRAN DANGKAL } \\
\hline tide & freq & amp & amp_err & pha & pha_err & snr & Nama KOMPONEN \\
\hline *M6 & 0.241534 & 0.0058 & 0.002 & 267.62 & 22.57 & 7.8 & $\begin{array}{l}\text { Shallow water overtides of } \\
\text { principal lunar }\end{array}$ \\
\hline${ }^{*} \mathrm{MS} 4$ & 0.163845 & 0.0084 & 0.004 & 317.57 & 25.37 & 5.4 & $\begin{array}{l}\text { Shallow water quarter diurna } \\
\text { Shallow water overtides of }\end{array}$ \\
\hline *S4 & 0.166667 & 0.006 & 0.004 & 359.84 & 34.08 & 2.8 & principal solar \\
\hline *M8 & 0.322046 & 0.0017 & 0.001 & 30.99 & 42.25 & 2.4 & $\begin{array}{l}\text { Shallow water eighth diurnal } \\
\text { Shallow water overtides of }\end{array}$ \\
\hline${ }^{*} \mathrm{M} 4$ & 0.161023 & 0.0051 & 0.004 & 262.83 & 42.92 & 2 & principal lunar \\
\hline${ }^{*} \mathrm{MK} 3$ & 0.122292 & 0.0049 & 0.004 & 238.72 & 39.86 & 1.8 & Shallow water terdiurnal \\
\hline
\end{tabular}

Kemudian untuk hasil proses perekaman pada kedalaman 250 meter mendapatkan komponen arus diurnal paling dominan adalah O1 (Lunar Diurnal) dengan frekuensi 0.038731 , tipe semi diurnal dominan adalah M2 (Prinsipal Lunar Semi Diurnal) dengan frekuensi 0.080511 , pada periode panjang mendapatkan konstanta MSF (Lunisolar synodicfornightly) mempunyai frekuensi 0.002828 dan perairan dangkal mempunyai konstanta MK3 (Shallow water terdiurnal) dengan frekuensi 0.122292 . Pada kerekaman alat kedalaman 350 meter mendapatkan komponen harmonik yang signifikan pada tepe diurnal mendapatkan konstanta O1 (Lunar Diurnal) dengan frekuensi 0.038731 , semi diurnal signifikan terdapat MU2 (Variational) dengan frekuensi 0.07769 , periode panjang MSF dan perairan dangkal adalah M4 (Shallow Water Overtides of Principal Lunar) dengan frekuensi 0.161023. Untuk kedalaman 450 meter mendapatkan komponen signifikan paling dominan tipe diurnal $\mathrm{O} 1$, semi diurnal MU2, periode panjang MSF dan periode perairan dangkal M4. Untuk hasil pengolahan komponen harmonik pada kedalaman 100 meter s/d 450 meter pada perekaman alat west mooring deployment 1 dilustrasikan pada gambar 3 . 


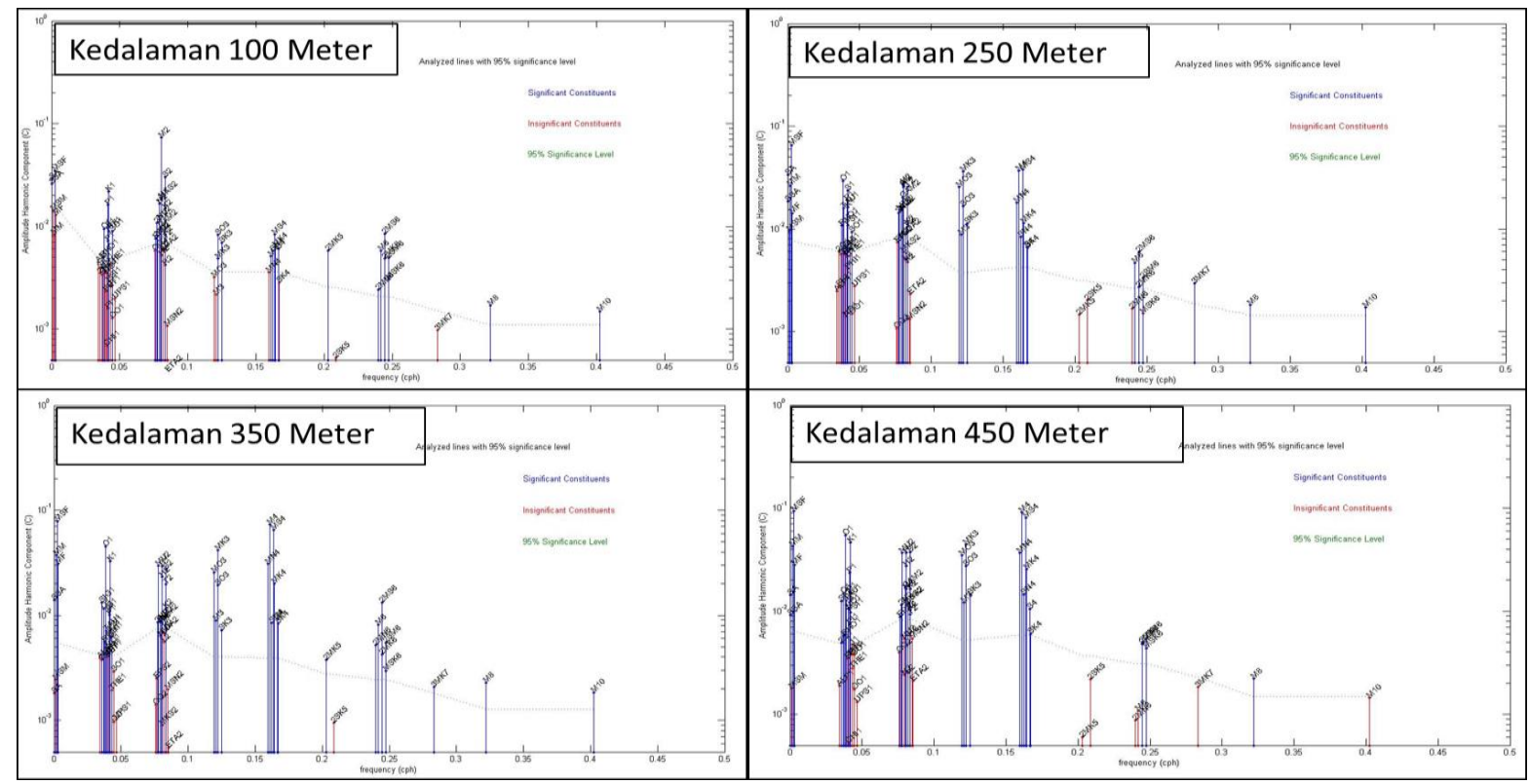

Gambar 3. Grafik hasil komponen harmonik pada kedalaman 100 meter s/d 450 meter.

Dari komponen harmonik diatas memiliki keterangan bahwa komponen tipe diurnal K1 adalah deklinasi sistem bulan dan matahari selama 23.93 jam, P1 adalah deklinasi matahari selama 24.07 jam, S1 adalah gravitasi matahari dengan orbit lingkaran dan sejajar ekuotor bumi dgn periode 24.00 jam, 01 adalah deklinasi bulan dengan periode 25.82 jam. Kemudian untuk tipe semi diurnal M2 adalah gravitasi bulan dengan orbit lingkaran dan sejajar ekuator bumi dengan periode 12.42 jam, S2 adalah gravitasi matahari dengan orbit lingkaran dan sejajar ekuotor bumi dengan periode 12.00 jam, N2 adalah perubahan jarak bulan ke bumi akibat lintasan yang berbentuk elips dengan periode 12.66 jam, K2 adalah perubahan jarak matahari ke bumi akibat lintasan yang berbentuk elips dengan periode 11.97 jam. Pada komponen periode panjang mendapatkan Msf adalah variasi setengah bulanan dgn Periode 354.3670 jam, SA adalah variasi tahunan dengan Periode 8766.15265 jam, SSA adalah variasi semi tahunan dengan Periode 4383.0763 jam, MF adalah variasi bulanan dgn Periode 354.3670 jam. Sedangkan untuk perairan dangkal mendapatkan S4 adalah $2 x$ S2 dengan Periode 6 jam, M6 adalah 3x kecepatan M2 dgn Periode 4.1402 jam, Ms4 adalah interaksi M2 dan S2 dgn Periode 6.1033 jam, M8 adalah 4x M2 dengan Periode 3.1015 jam, M4 adalah 2x M2 dengan Periode 6.2103 jam, MK3 adalah interaksi bulan dan matahari dengan perubahan jarak bulan akibat lintasan berbentuk elips dgn periode 8.18 jam. Pada kedalaman 350 meter dan 450 meter memiliki komponen SNR ( Signifikan Noise to Ratio) terbesar adalah komponen harmonic M4, MS4, MSF, O1, dimana komponen M4 merupakan hasil dari 2xM2 dimana M2 adalah komponen semi diurnal, koponen MS4 merupakan komponen campuran/perairan dangkal, MSF merupakan komponen periode panjang dan $\mathrm{O} 1$ merupakan komponen diurnal. Tekankan komponen tersebut mengindikasikan penjalaran gelombang panjang samudera hindia masuk ke selat Lombok. Pasang di Selat Lombok dihasilkan oleh gelombang pasang dari samudera Hindia dan di wilayah sill, gelombang tersebut didominasi semi diurnal. Namun, air pasang di bagian utara selat Lombok didominasi siklus diurnal dan amplitudo arus harmonik (Murray and Arief, 1988).

\subsection{Kecepatan dan pola arus tiap kedalaman}

Hasil dari pengolahan west mooring deployment 1 di Selat Lombok dengan periode pengamatan selama 1.5 (satu setengah) tahun pada 9 Januari 2004 s/d 14 Juni 2005 pada kedalaman 100 meter mendapatkan arus harmonik maksimum sebesar $1.124542 \mathrm{~m} / \mathrm{s}$, arus harmonik minimum sebesar $0.00028263 \mathrm{~m} / \mathrm{s}$, dan ratarata arus harmonic sebesar $0.25219 \mathrm{~m} / \mathrm{s}$. Untuk kecepatan arus harmonik pada kedalaman 250 meter, 350 meter, dan 450 meter dapat dilihat pada tabel 1 . 
Tabel 1. Hasil pengolahan kecepatan arus harmonik pada kedalaman 100 meter, 250 meter, 350 meter, 450 meter.

\begin{tabular}{cccc}
\hline \multicolumn{4}{c}{ Arus Harmonik } \\
\hline Kedalaman $(\mathrm{m})$ & $\operatorname{Max}(\mathrm{m} / \mathrm{s})$ & $\operatorname{Min}(\mathrm{m} / \mathrm{s})$ & Rata-Rata $(\mathrm{m} / \mathrm{s})$ \\
\hline 100 & 1.124542 & 0.00028263 & 0.25219 \\
250 & 0.9539 & 0.0012048 & 0.22447 \\
350 & 0.9653 & 0.002778 & 0.25871 \\
450 & 1.0214 & 0.0012545 & 0.27432 \\
\hline
\end{tabular}

Pola arus di Selat Lombok berdasarkan hasil pengolahan dengan menggunakan modul $t$ tide 1.3 beta mendapatkan hasil dengan bentuk Current Rose pada kedalman 100 meter, 250 meter, 350 meter dan 450 meter, dapat dilihat pada gambar 4 . Pada

kedalaman 100 meter kecepatan arus dominan menuju ke selatan dan barat daya dengan kecepatan arus maksimum rata-rata $1.1 \mathrm{~m} / \mathrm{s}$ dan memiliki kecepatan maksimum rata-rata 0.1 menutu ke utara dan timur laut, kemudian pada kedalaman 250 meter arah arus masih dominan menuju selatan dan barat daya sengan kecepatan maksimum rata-rata $0.9 \mathrm{~m} / \mathrm{s}$ dan memiliki kecepatan maksimum rata-rata sebesar 0.6 ke arah utara, sedangkan pada kedalaman 350 meter arah arus cenderung menuju ke utara dan timur laut dengan kecepatan maksimum ratarata $0.9 \mathrm{~m} / \mathrm{s}$ tetapi sebagian arah juga masik menuju ke selatan dan barat daya dengan kecepatan maksimum rata-rata 0.8 , begitu juga pada kedalaman 450 meter arah arus dominan menuju ke utara dan timur laut dan sebagaian menuju ke selatan dan barat daya dengan kecepatan arus maksimum rata-rata $1.0 \mathrm{~m} / \mathrm{s}$ ke utara dan timur laut kemudian mendapatkan nilai $0.9 \mathrm{~m} / \mathrm{s}$ menuju ke selatan dan barat daya.

Hasil kedalaman current rose pada kedalaman 100 meter s/d 250 meter kecepatan dan arah arus cenderung menuju ke selatan dan barat daya, hal ini dipengaruhi oleh ARLINDO yaitu terbukti dengan didapatnya konstanta arus periode panjang seperti SA, SSA dan MSF, konstanta periode panjang tersebut adalah variasi bulanan dan tahunan yang dipengaruhi oleh matahari dan bulan. Selain dari konstanta arus, ARLINDO juga dipegaruhi oleh cuaca, densitas, pasut, topografi dan bathimetri. Terjadinya Arlindo terutama disebabkan oleh perbedaan tinggi muka laut antara Lautan Pasifik dan Lautan Hindia, yaitu permukaan bagian tropik Lautan Pasifik Barat lebih tinggi dari pada Lautan Hindia bagian timur, sehingga terjadi gradien tekanan yang mengakibatkan mengalirnya arus dari Lautan Pasifik ke Lautan Hindia (Hasanudin, 1998).

Arlindo membawa massa air samudra Pasifik memasuki perairan Indonesia melalui dua jalur, yaitu jalur barat yang masuk melalui laut Sulawesi lalu ke selat Makassar, Laut Flores, dan ke Laut Banda. Jalur kedua adalah jalur timur yang melalui Laut Maluku dan Laut Halmahera lalu ke Laut Banda. Massa air ini akan keluar menuju Samudra Hindia terutama melalui Laut Timor. Jalur keluar lainnya melalui Selat Ombai, yaitu selat antara Alor dan Timor, serta melalui Selat Lombok (Fieux et al., 1996).

Tetapi pada kedalaman 350 meter s/d 450 meter terjadi pola arus yang sangat menarik yaitu kecepatan dan arah arus cenderung menuju ke utara dan timur laut serta selatan dan barat daya. $\mathrm{Hal}$ ini disebabkan oleh pengaruh ARLINDO dan pengaruh gelombang panjang dari samudra hindia yang masuk ke selat lombok. Gelombang panjang tersebut kemudian membentuk internal wave ketika gelombang tersebut melewati sill (gundukan didasar laut) saat propagasinya/penjalarannya memasuki selat lombok (Susanto et al., 2005). Untuk internal wave (gelombang panjang) yang teridentifikasi melalui citra satelit radar di Selat Lombok, pernah diteliti sebelumnya oleh Susanto (2005), dapat dilihat pada Gambar 5. 


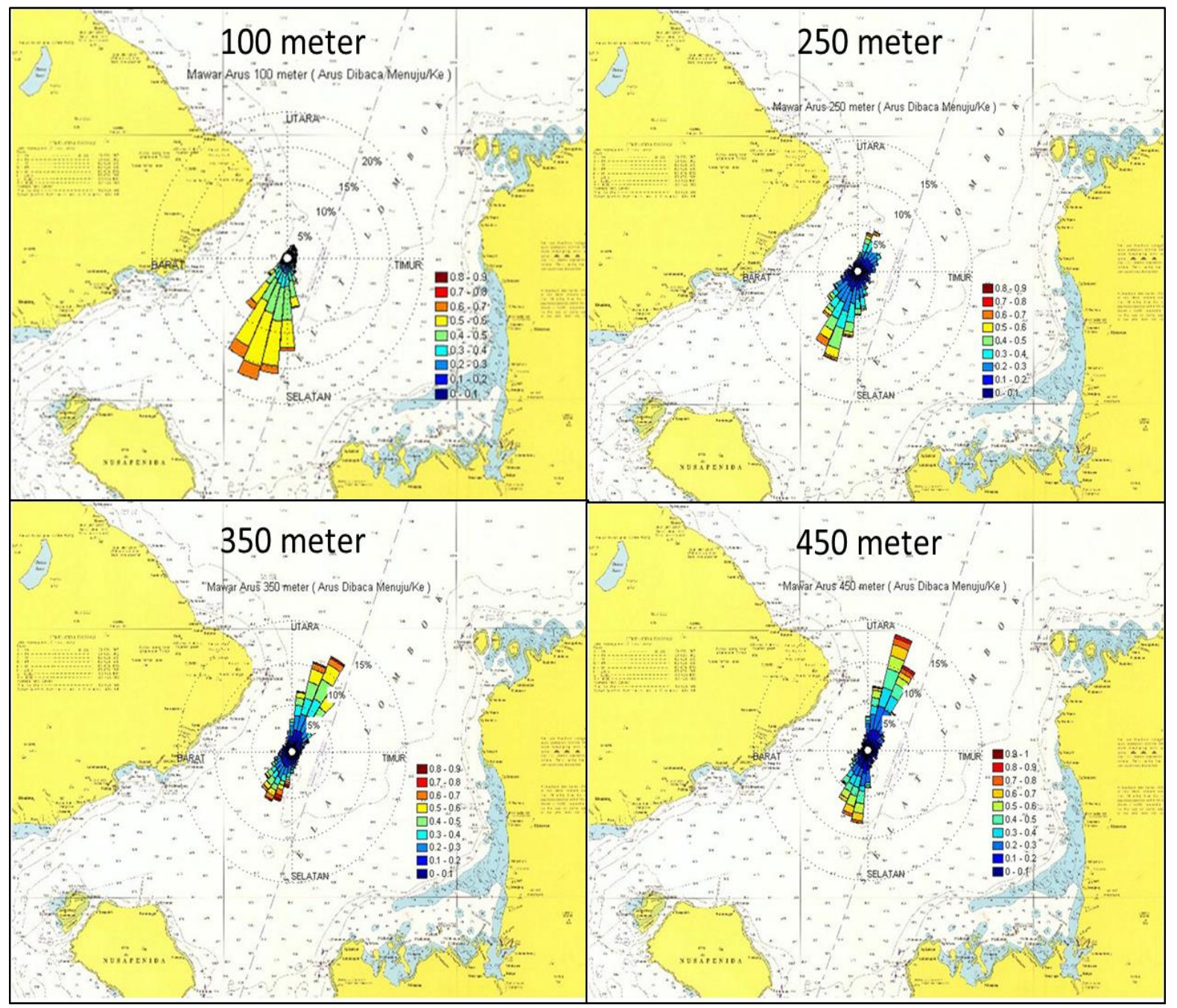

Gambar 4. Current Rose Pada Kedalaman 100 meter, 250 meter, 350 meter dan 450 meter.
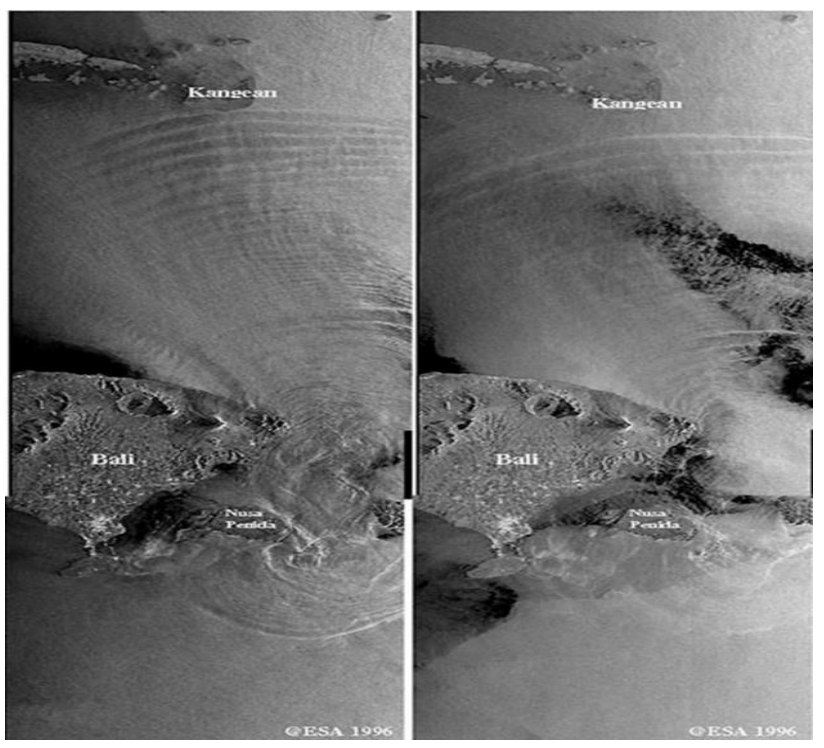

Gambar 5. Internal Wave Selat Lombok (Susanto, 2005) 


\section{Kesimpulan}

Selat Lombok merupakan merupakan salah satu selat yang dilintasi oleh ARLINDO, hal ini terbukti dengan terdapatnya komponen periode panjang seperti SA, SSA dan MSF, dengan memiliki kecepatan arus harmonik maksimum pada kedalaman 100 meter sebesar $1.124542 \mathrm{~m} / \mathrm{s}$, arus harmonik minimum $0.00028263 \mathrm{~m} / \mathrm{s}$ dan rata-rata arus harmonik $0.25219 \mathrm{~m} / \mathrm{s}$, dengan kecepatan arus maksimum rata-rata $1.1 \mathrm{~m} / \mathrm{s}$ kearah selatan dan barat daya dan memiliki kecepatan maksimum rata-rata 0.1 menuju ke utara dan timur laut. Data arus laut dari perekaman diolah menggunakan modul tool box matlab t-tide 1.3 beta mendapatkan arus harmonik, current rose, komponen harmonik signifikan seperti komponen $\mathrm{O} 1$ pada tipe diurnal, semi diurnal terdapat $M 2$, periode panjang mendapatkan komponen SA, SSA, MSF dan pada perairan dangkal mendapatkan komponen harmonik signifikan M6. Pengaruh internal wave berdasarkan SNR (Significant Noise to Ratio) adalah komponen harmonic M4, MS4, MSF dan O1. Pada kedalaman 350 meter dan 450 meter terjadi pola arus yang sangat menarik yaitu kecepatan dan arah arus cenderung menuju ke utara dan timur laut serta selatan dan barat daya. Hal ini disebabkan oleh pengaruh ARLINDO dan pengaruh gelombang panjang dari Samudra Hindia yang masuk ke Selat Lombok. Gelombang panjang tersebut kemudian membentuk internal wave ketika gelombang tersebut melewati sill (gundukan didasar laut) saat propagasinya/penjalarannya memasuki selat Lombok.

\section{Ucapan Terima Kasih}

Artikel ini merupakan karya tulis ilmiah bagian dari Tugas Akhir Program Studi S1 STTAL Jurusan Hidrografi dari penulis pertama, dengan dibimbing dan diuji oleh para penulis mitra (co-authors). Kami berterima kasih kepada lembaga STTAL Jurusan Hidrografi, dan para dosen pembimbing. Kami ucapkan terimakasih kepada Pusat Penelitian dan Pengembangan Sumberdaya Laut dan Pesisir (P3SDLP) yang telah memberikan akses data INSTANT project 2004 s/d 2005 dan fasilitas Laboratorium Data laut dan Pesisir untuk melaksanakan penelitian dan pengolahan data INSTANT mooring deployment 1 di Selat Lombok tersebut. Penyusunan dan penerbitan artikel adalah dibiayai oleh APBN DIPA P3SDLP TA. 2015/2016.

\section{Daftar Pustaka}

Cappenberg, 1992. Von der Burg zur Kirche Ausgrabungen im Chor der ehem. Prämonstratenserstiftskirche St. Johannes Ev. In Selm-Cappenberg 1992-93.

Fieux, M., Andrie, C., Charriaud, E., Ilahude, A.G., Metzl, N., Molcard, R., Swallow, J.C. 1996. Hydrological and Chlorofluoromethane Measurements of The Indonesian Throghflow Entering The Indonesian Ocean. Journal of Geophysical Research 101,1243312454.

Gordon, A.L., Susanto, R.D., Ffield, A., Huber, B.A., Pranowo, W., Wirasantosa, S. 2008. Makassar Strait throughflow, 2004 to 2006. Geophysical Research Letters 35, L24605, doi:10.1029/2008GL036372.

Hasanudin, M. 1998. Arus lintas Indonesia (ARLINDO). Oseana, 23(2):1-9.

Murray, S. P., Arief, D. 1988. Throughflow into the Indian Ocean through Lombok Strait, January 1985-January 1986. Nature 333, 444-447.

Pawlowicz, R., Beardsley, B., Lentz, S. 2002 Classical tidal harmonic analysis including error estimates inMATLAB using T TIDE, Pergamon. Computers \& Geosciences 28, 929-937.

Pranowo, W.S., Tisiana Dwi Kuswardani, A.R., Kepel, T.L., Kadarwati, U.R., Makarim, S. Husrin, S. 2006. Ekspedisi INSTANT 2003-2005: Menguak Arus Lintas Indonesia, editors: Supangat, A., I. S. Brodjonegoro, A. G. Ilahude, I. Jaya, T. R. Adi., Pusat Riset Wilayah Laut \& Sumberdaya Non-hayati. Badan Riset Kelautan \& Perikanan. Departemen Kelautan \& Perikanan.

Purba, N.P., adn Pranowo, W; 2005; Dinamika Oseanografi, Deskripsi Karakteristik Massa Air dan Sirkulasi Air Laut. UNPAD Press. 276 pages.

Susanto, R. D., Mitnik, L., Zheng, Q. 2005. Ocean internal waves observed in the Lombok Strait. Oceanography 18, 8187.

Wyrtki, K. 1961. The physical oceanography of south east Asian waters. Naga Report Vol. 2. University California Press. La Jolla, California. 195p. 